\title{
T-Cell Leukemia Translocation-Altered Gene Protein
}

National Cancer Institute

\section{Source}

National Cancer Institute. T-Cell Leukemia Translocation-Altered Gene Protein. NCI

Thesaurus. Code C30082.

T-cell leukemia translocation-altered gene protein (103 aa, $\sim 11 \mathrm{kDa}$ ) is encoded by the human TCTA gene. This protein may play a role in osteoclast development. 